\title{
Making lit a hit: Teaching and learning poetry in grade 9 through songs and calligrams
}

\author{
Nieves, Tricia Paula F. $\triangle$ \\ Laguna College of Business and Arts, Philippines (tpnieves22@gmail.com)
}

Recillo, Maria Luisa B.

City College of Calamba, Philippines

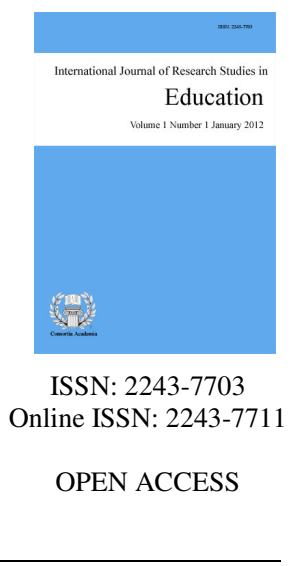

Received: 24 July 2021

\section{Abstract}

This study focused on the lived experiences of Grade 9 English teachers and students when dealing with poetry through songs and calligrams in the selected private schools in Cabuyao and Calamba. This study was conducted to discover what were the experiences the teachers and students encountered when they dealt with poetry using the traditional method and then shifting to using songs and calligrams. The study used interpretative phenomenological analysis using qualitative research design. A validated self-made questionnaire was used during the multiple in-depth interviews with the participants to gather qualitative data in order to gather the difficulties, challenges, and how they coped when the participants experienced using songs and calligrams as well as traditional method in dealing with poetry. Qualitative data showed that the participants experienced difficulties when dealing with poetry using the traditional method during class discussion, unlike with songs and calligrams that showed how helpful it was for both participants. In addition, the participants' answers reveal that there was an improvement in the performance of the participants when songs and calligrams were used when they dealt with poetry. Despite these difficulties experienced by the participants, using a modern method such as songs and calligrams helped both participants to help them achieve performance progress compared to using the traditional method in dealing with poetry. The integration of both techniques in teaching and learning poetry will be helpful fo both teachers and students to achieve higher success of learning. For the output, a compendium of poems and songs was proposed.

Keywords: literature, songs, calligrams, teaching, learning poetry 


\section{Making lit a hit: Teaching and learning poetry in grade 9 through songs and calligrams}

\section{Introduction}

Most educational systems in the world present common features of the various facets of the academic structure: updated curricula for 21 st century environment, fast-changing media, learners' skills in communication and modern technologies, and new teaching techniques and resources. In essence, the scientific world view has produced academic systems which focused on cognitive learning, where results could be accurately and objectively assessed.

Locally, these policies are still evident as proven by the present breed of learners in the secondary level who do not engage in extended, more profound, and truly delightful learning that promotes their creative ingenuity and unlimited imagination, like literature. As such, the study of belles lettres opened a new kind of learning - an aesthetic education that includes longer and more enjoyable exposure to literature. But such a condition has not been found in many academic entities. This has been a long-standing concern and one that results from a traditional, unbalanced, and congested curriculum that does not allow long engagement for the interior being of the learners, which a longer and in-depth study of literature provides.

Ironically, literature has been a vital part of Philippine culture and of the educational system since time immemorial and teachers share literature to students for them not only to grasp and understand but also to appreciate its aesthetic beauty. Hence, teachers looked for ways to teach literature effectively, but to no avail for it remains a challenging field of study for both teachers and students for several valid reasons: reading long pieces of literature has such been a boring activity; it has been only a means of teaching and learning language; some topics for study have not been interesting; non-literature major teachers do not know how to teach it; and some literary genres, like poetry, have been difficult to study. Considering what is ahead, such concerns call for a renewed vision of literature education that is centered on the ideals of a more refined approach that can equip students with the sensitivities and dispositions of the current world trend of globalization which is essential in developing global citizens.

Hence, in keeping with the said vision and the 21 st century objective of creating an academic environment that addresses the needs of the global citizens in the fields of the humanities and the arts, specifically in Literature, this study aimed to look into the experiences of Grade 9 English teachers and students of the Selected Private School in Cabuyao and Calamba as they dealt with the teaching and learning of literature, specifically of poetry, through songs and calligrams

\subsection{Theoretical Framework}

This study is anchored on three theories: The Multimodality Theory of Mark Dressman (2010 as cited in Xerri, 2012), The Constructivism Theory of Lev Vygotsky (1978 as cited in Wijayanti, 2013), and David Kolb's (1964 as cited in Singh, 2013) theory of Experiential Learning. The Multimodality Theory of Mark Dressman (2010 as cited in Xerri, 2012) makes use of several semiotic modes in the design of a semiotic product or event, together with the particular way in which these modes are combined. It is "the crafted integration of two or more modes of communication, so that their combined meaning as a whole is greater than either mode separately or their simple combination" (Dressman as cited in Xerri, 2012). This usually, but not exclusively, involves the use of digital technology, and given the different and evolving ways of communication that contemporary students can utilize to communicate meaning and understand the world, a multimodal approach is necessary. What relates different design elements (i.e., linguistic, visual, audio, gestural, and spatial) to each other are the Multimodal patterns of meaning which involves the development of students' use of multiliteracies in the composition and comprehension of texts in computer-based and conventional formats. 
A multimodal approach presents students with different potentials for their deep engagement with a text: the point of entry, the possible paths through a text, and the potentials for re-making it. In multimodal texts, each mode offers a different way into representation and focuses on different aspects of meaning. The notion of this multimodality redefines pedagogy because learning itself is reconceptualized, partly because of the impact of new technologies. The increasingly and insistently more multimodal forms of contemporary texts make it essential to rethink the notions of what reading is.

A multimodal approach is one where attention is given to all the culturally-shaped resources that are available. They consider it essential due to "the ways in which it creates new kinds of identity for students and teachers (Kress, et al., 2005 as cited in Xerri, 2012). It may actually lead to a re-evaluation of the teacher/learner hierarchy: changing learners in changing times may eventually alter how teachers view the expert/novice relationship. This is particularly significant when one takes into consideration the traditional role of poetry teachers as gatekeepers to a poem's meaning through songs and calligrams.

On the other hand, the Constructivism Theory of Lev Vygotsky (1978 as cited in Wijayanti, 2013) is a language theory to help the students in constructing something based on their own understanding. It emphasizes the students' role than that of the teachers' in that learning is based on context through the learners' interaction with others. The role of the teacher is to ask the students to learn to construct meaning and to assimilate and accommodate the students' prior knowledge and the new ones.

Vygotsky, from the view of socio-cultural perspectives, assumed that the theory came from the theory of language, thought, and mediation in the social environment. He believed that learning occurs via construction of meaning in social interaction within cultures and through language; that knowledge is not transferred from teachers to students but constructed in the students' mind. For him, the language classroom should have been characterized by the following: its goal is emphasized in collaborative meaning; the role of teacher is as facilitator who monitors the students' thinking; and there is social interaction.

Lastly, David Kolb's (1964 as cited in Singh, 2013) theory of Experiential Learning, which is based on ideals of active and reflective learning thorough experiences with the personal involvement of the learner, argues that human beings generate knowledge and meaning from their own experiences. Knowledge is actively constructed by learners, but not passively received from the environment that surrounds them or from their teachers. Experiential learning explores the cyclical pattern of learning from experience through reflection and conceptualizing to action and on to further experience.

Based on the four stages of David Kolb's learning cycle, Honey and Mumford Experiential learning encourages personal input, initiative, and self-direction in the language learning process. Activities begin with accessing the specific past experiences of students, and using these experiences to construct a framework for learning unique to the requirements and learning style of each student. In practice, experience-based, project-based, task-based learning, and game-based learning become experiential when elements of reflection, support, and transfer are added to the basic experience, transforming a simple activity into an opportunity for language learning. Experiential learning also requires teachers to take on a different role in the classroom than the traditional teacher as an expert. In the classroom, they become facilitators, guides, and helpers (Singh, 2016).

In English Language Teaching, the experiential approach encourages learners to develop the target language skills through the experience of working together on a specific task. Implementation of this theoretical approach through language games in the classroom opens a new vista for learners to learn language by using it in real context and be able to explain what they are learning and how they are learning and grade themselves as a way to measure their strengths and weaknesses. Language learning is accelerated when learners are supportively involved in activities cum games which include exposure, participation, internalization, and dissemination to provide opportunities for language learning and create an environment to sustain motivation to learn the target language (Brown, 2000 as cited in Singh, 2016). 


\section{Conceptual Framework}

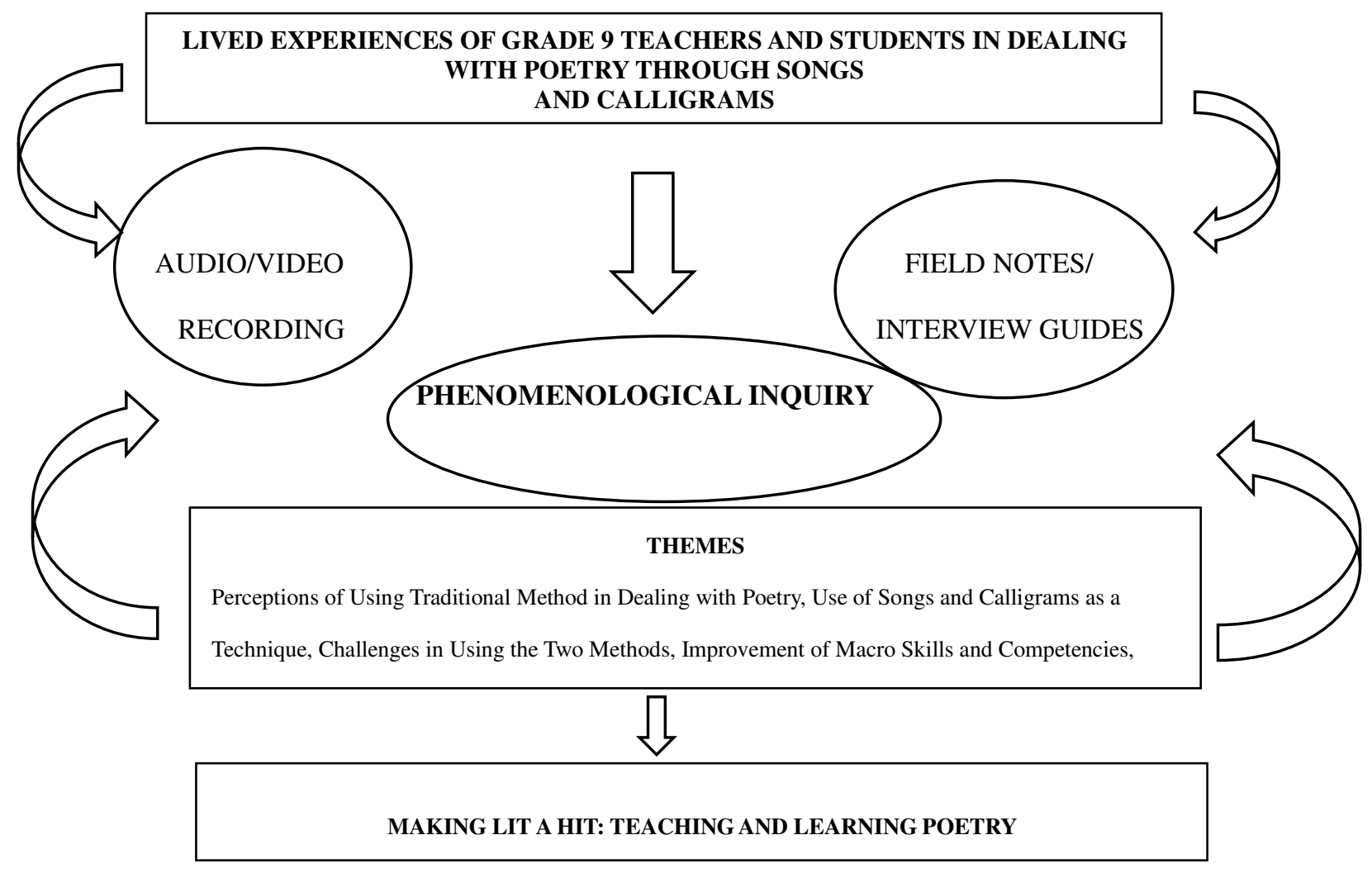

Figure 1. Paradigm of the Study

\subsection{Central and Corollary Questions}

The main objective of this study was to look into the experiences of English 9 teachers and students in teaching and learning poetry through songs and calligrams in the 21 st century classroom setting. The study aimed to answer the central question,

$>\quad$ What is the essence of the lived experiences of English 9 teachers and students in dealing with poetry through songs and calligrams in the 21 st century classroom?

\subsection{Corollary Questions:}

$>\quad$ How do the Grade 9 English teachers and students of the two selected private schools in Cabuyao and Calamba describe their experiences in teaching and learning poetry through songs and calligrams?

$>$ Based on the testimonies of the co-researchers, what themes emerged?

$>\quad$ Based on the findings of the study, what compendium of songs and calligrams may be proposed to help English teachers teach literature more creatively and for the students to learn more delightfully?

\subsection{Scope and Delimitation of the Study}

The study focused on the lived experiences of the Grade 9 English teachers and students in dealing with poetry through songs and calligrams. This included the qualitative type of research to gather the data needed for the study. The Multimodality Theory which uses various modes of communication and language learning was used in the teaching and learning of poetry through songs and calligrams. This study included two private schools in Cabuyao and Calamba, Liceo de Mamatid and St. Benilde International School. All Grade Nine 
English Teachers and 6 Grade Nine students in these schools were interviewed based on their time availability. This study covered the school year 2020-2021.

\section{Review of Related Literature}

Literature has been taught in school since time immemorial because literature holds a big part of the unspoken history, social cultures, norms, and traditions that can be read and taught for generations to come. There is a separate class for literature to give value and importance to the beauty and essence of a society and a person's life. Hennessy, Hinchion, McNamara, and Mohammed (as cited by Sugandi \& Husnaini, 2015), Long (2015), Collie and Slater (1987 as cited in Alfauzan \& Hussain, 2016), Diyanni (2002, as cited in Mohammed, 2013) and Kramsch (1993 as cited in Tevdovska, 2017) believed that literature indeed constitutes a big part of man's life. It has been taught in traditional schools and it's still being offered either as a separate course or a component of the modern language curriculum. It helps people understand how life works with its unspoken history, social norms, values, and culture that can be taught to all generations.

On the other hand, Widdowson (1975 as cited in Alfauzan \& Hussain, 2016), Moon (2000 as cited in Alfauzan \& Hussain, 2016), Ferradas (2009 as cited in Keshavarzi, 2015), Abuzahra and Farrah (2016), Lazar (1993, cited in Siaj \& Farrah, 2018), Kataja (2018), and Alfauzan and Hussain (2016) said that literature is used to help learners in their language acquisition since literature bears an understanding of the holistic formation of the individual and the context of language skills. As literature provides numerous ways on how other aspect of knowledge acquisition can be gained such as learning vocabulary words and development of critical thinking through questions provided for comprehension check during and after the discussion of each literary texts.

Literature appreciation means appreciation of poetry, too. According to Carol Fishner, Khansir, Hismanoglu, and Saraç (as cited by Syed \& Wahas 2020), and Maples, Cianca, and Maloy (2016) children need to be exposed to literature especially poems because they are the best mirrors of life where children can learn from so much. In teaching poetry, the researcher thinks that teachers must know what poems are appropriate for students' age. They also believe that as the children grow with love for and appreciation of poetry, they will be more open and understanding with the true meaning of life that may come in handy when the time comes.

Obediat (as cited in Choudhary, 2016), Abraham (as cited in Habeeb \& Firwana, 2015), Parkinson and Thomas (2000 as cited in Sugandi \& Husnaini, 2015), and Collie and Slater (as cited in Arafah, 2018) stated that literature are helpful in the development of language skills such as writing, reading, speaking and listening that help students to be critical thinker, imaginative and creative as the pre-requisite for language learning is the students need to have the feeling of the language in the course of learning literature.

Additionally, as stated in Cubuku (as cited in Sugandi \& Husnaini, 2015), Killander (as cited in Haniya, 2019), Davis (as cited in Karasfi, 2016), and (Marsh, 2020) there are challenges encountered by both teacher and learners with literature specifically with poetry. They believe that teachers should provide literary texts that are of the level of the students as the deeper the meaning of the literary texts presented to the students, difficult it is for them to understand the idea and context. In learning literature, the interest and that can evoke objective and subjective feeling on both students and teachers.

Songs are a big part of one's life and people say that music is life and that without it, the world is dull and bland. According to Jensen (2000 as cited in Snyder 2016), The Editorial Team (2020), Ludescher (2020), Bennett (as cited in Liikkanen \& Jakubowski, 2020), and Morrisson (2020), songs make learning fun and exciting due to their simple beat and rhythm; thus, students can enjoy and learn a certain context fast and with retention for its mnemonic device. It is because songs can stimulate all the senses in the body. It is believed that using songs in teaching poetry is very helpful and handy because poems are songs without musical arrangement. If sounds are incorporated in teaching poetry, students will surely enjoy the class without thinking that learning poetry is boring and no fun at all. 
Meanwhile, Art Sprouts (2019), Bateni (as cited in Karasfi, 2016), Simpson (as cited in Nordoquist, 2020), Mahmoudi (as cited in Karasfi, 2016), Shamisa (as cited in Saadatnoori, Moshayedi, \& Haidary, 2020), Leech (as cited in Karasfi, 2016), Cummins (2020) stated that visual poetry will allow students to create their image of the poem they read through words. Teachers can use calligrams in class to allow the students to craft their poem by allowing them to form it based on the images in the poem they are about to create. The researcher believes that the combination of poetry and visuals can be one of the many tools to address the decreasing number of students who lack interest and understanding of poetry as most learners in a class are visual learners.

Thus, the present study is unique in the sense that it is one of the few studies on literature and how to make it a more exciting, challenging yet delightful, and spiritually uplifting course load for teachers and equally interesting, appreciated, and academically acceptable subject for students, specifically on teaching and learning poetry through music (songs) and images (calligrams). It focuses on the way both teachers and students of Grade 9 from Liceo de Mamatid and St. Benilde International School dealt with the challenges of teaching and learning poetry with songs and calligrams. The main concern of the study was to know how teachers and students used songs and calligrams as tools in teaching and learning literature in a language class.

\section{Methodology}

Research Design - The study utilized the qualitative research with Interpretative Phenomenology Analysis (IPA) as approach. This approach is used when the researcher's aim is to explore in detail how participants are making sense of their personal and social world, and the main currency for an IPA study is the meaning's particular experiences, and events, and states hold for participants (Smith, et al., 2009 as cited in Alase, 2017). The approach is phenomenological in that it involves detailed examination of the participant's lifeworld; it attempts to explore personal experience and is concerned with an individual's personal perception or account of an object or event, as opposed to an attempt to produce an objective statement of the object or event itself. At the same time, IPA also emphasizes that the research exercise is a dynamic process with an active role for the researcher in that process. One is trying to get close to the participant's personal world, an insider's perspective, but one cannot do this directly or completely. Consistent with its phenomenological origins, IPA is concerned with trying to understand what it is like, from the point of view of the participants, to take their side. The ordinary word 'understanding' usefully captures these two aspects of interpretation-understanding in the sense of identifying or empathizing with and understanding as trying to make sense of. This research design is appropriate to the study since the researcher looked into the lived experiences of English 9 teachers and students of Liceo de Mamatid and St. Benilde International School in dealing with poetry through songs and calligrams in the classroom.

Instrument of the Study - This researcher sought answers to the questions given in the statement of the problem to attain a solid conclusion based on the data gathered from the researcher's interviews and observations. The purpose of such method was to gather the information and observation of the English teachers and their students on the use of songs and calligrams in dealing with poetry in the classroom through the use of self-made instrument, the structured interview questionnaire. In gathering pertinent information, the researcher used 10 guided questions which were used as interview questions for the English teachers and their students as her participants.

Participants of the Study - The participants of the study were Grade Nine English teachers and students from Liceo de Mamatid and St. Benilde International School, regardless whether they were new or tenured teacher and new or transferee students. These participants were interviewed based on the given time the researcher and the participants agreed upon.

Data Gathering Procedure - Initially, a letter asking for permission to conduct the study was done. This was addressed to the Principal's offices. It was sent online (gmail) to observe social distancing. After the approval, the researcher scheduled the interview session. The researcher prepared the self-made interview questionnaire, recorders, and camera for recording purposes. The researcher communicated with the participants through google 
meet to discuss the importance and objectives of the study, the copies of the questions using google forms and sheets, in google classroom, and ZOOM app for the interviews. Data collected were subjected to appropriate transcription, conversion, and coding. Also, the teachers were asked to provide sample print-outs of the learning materials that they used in teaching poetry inside the classroom. This was done with the permission from the participants and were subjected to analysis and data-gathering which was used to finalize the interview questions. After collecting the data using the interview, the researcher proceeded to the next part which was the transcription of the responses. After the transcription, the researcher encoded, then transcribed the responses and these were subjected to analysis to formulate themes. Amid a context of enormous challenges with the COVID-19 pandemic, learning was move from face-to-face teaching to online teaching.

\section{Results and discussions}

There are ten (10) emerging themes. They are as follows: Perceptions of Using Traditional Method in Dealing with Poetry, Use of Songs and Calligrams as a Technique, Challenges in Using the Two Methods, Improvement of Macro Skills and Competencies, Observed Changes in the Students during Transition Period, Suggestions in Using Songs and Calligrams, Students' Performance in Both Techniques, Challenges in Oral and Written Discourse, Addressing the Challenges in Both Methods, and Comparison of Using the Two Techniques.

\section{USING OF SONGS AND CALLIGRAMS IN TEACHING AND LEARNING POETRY}

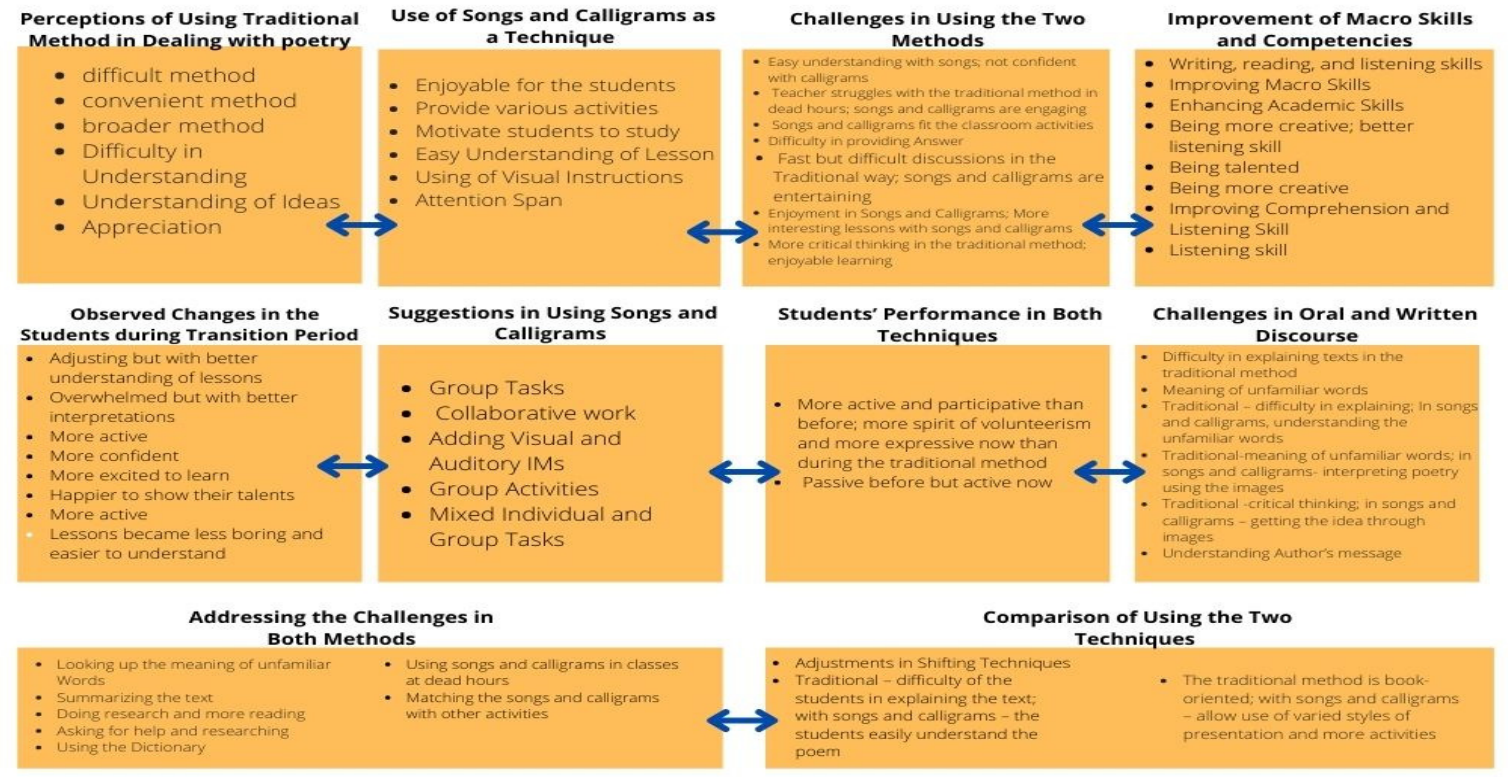

Figure 2. Emerging Themes

\subsection{Emerging Theme 1: Perceptions of Using Traditional Method in Dealing with poetry}

As what A reeve (1963 as cited in Sugandi \& Husnaini, 2015) argued, in the teaching of poetry, basically there are four factors to be considered: the pupils, the poems to be taught, the method to be adopted, and the personality of the teacher. It only means that since the traditional method has been the convenient way for teachers to teach literature to their students, they struggled to come up with their desire outcome at the end of every lesson as the students struggled with them in a way that they could not express the ideas they had due to lack of understanding not only of the content of the poem but in its entirety that leads to disinterest and a passive classroom atmosphere.

Furthermore, the texts that have been usually presented to students followed the historical approach which focused on the writer's biography and milieu and the social, cultural, and intellectual context. Indeed, a number of scholars and critics have repeatedly expressed their dissatisfaction with the unrepresentative selections and the 
traditional and outdated approaches to teaching them (Alamir, 2006, as cited in Al-Emami \& Hussein, 2016).

In addition, the main reason that made teaching and learning literature difficult among teachers and students in the traditional method were the outdated techniques which are still being used until today by some teachers despite the wide range of techniques and methods that can be helpful to both teachers and students. That is why there is an argument to go forth and beyond the traditional method of teaching literature (Al-Asmari \& Khan, 2014 as cited in Al-Emami \& Hussein, 2016) because in that way, both teachers and students will be able to overcome the difficulty they have every time they encounter literature in their classroom the features of which are mostly comprised of teacher explaining text, students listening, students reading aloud, teacher asking questions, and students answering questions (El-Helou, 2010).

For the past years, the traditional method has been and still being used by various teachers in both private and public schools, especially when some of the teachers are not aware of the latest trends and methods when it comes to teaching it that it results to unwavering misunderstanding and difficulty for both teachers and students. This is due to the fact that almost all of the time, it is the teacher who talks and explains and it turns out to be an active-passive response session for both ends (wherein teachers are active while students are passive). According to Lazar (1993 as cited in Tevdovska, 2016), content approach concentrates on imparting detailed factual knowledge about a few specific texts. The reasons why the content approach is so widely used are historical rather than pedagogical. Traditionally, literature as a subject, has always been taught by means of lectures on the content of specific texts or poems, especially at the university level. This is what both participants found difficult when talking about literature. It became a struggle for teachers to teach it because the students are no longer engaged and are passive when it comes to participation. No concrete response can be drawn. As for the students, learning literature become a routine for them to be able to pass the subject and not to learn and gain something because they struggle a lot in getting the essence of the texts being taught, especially they start learning about poetry.

Other studies also gave reason why both teachers and students are struggling and having a hard time in dealing with Literature when using the traditional method. According to El-Helou (2010), most English learners suffer a lot from studying literature such as drama, poetry, short story, and novel because there is a huge gap between these learners and literature. Unfortunately, few studies were carried out to show some problems which face teachers in teaching literature. Most of these studies discussed the importance of literature in the learners' life. Therefore, the teachers should be aware of these problems in order to overcome them and have a good attitude towards literature. Both participants narrated what they thought it would be if poetry has been taught through music. Music has been part of the humans' lives that in everything they do, they indulge themselves in music. The same goes with teaching and learning poetry; it would be more engaging if music and poetry goes hand-in-hand during the teaching-learning process.

According to Gardner (in his book "Frames of Mind", 1983 as cited by Navaratnam, 2009) there are eight distinct intelligences, namely, linguistic, spatial, kinesthetic, logical, musical, naturalistic, interpersonal, and intrapersonal. All humans possess these multiple intelligences in varying degrees. If this is true, teachers should be taking into account these individual differences when preparing or delivering lessons. There are various ways of how teachers can deal with literature and teach it to their students. Teachers cannot focus on what they already know as learners today are diverse in a way that they have different ways of learning an idea which may be difficult for others but convenient for them. Students nowadays best learn when teachers try to incorporate techniques that do not only arouse interest but attract attention, focus, and enjoyment among them. According to Bennett (2002), he has coined the phrase 'Musical Imagery Repetition' (MIR) to describe the involuntary recall and defines it as "previously heard music that, while consciously unintended, repeats uncontrollably and pervasively in thought" (2002). Most poetry is likely to be put into songs before they are taught inside the classroom so that students will enjoy learning poetry.

Music has mnemonic devices that can be used by students to allow them remember what the teacher has 
Making lit a hit: Teaching and learning poetry in grade 9 through songs and calligrams

taught them. With this mnemonic, use of songs in teaching and learning poetry will be helpful as it will allow students retain in their memory the poem taught to them because the beat and rhythm will allow them to remember it once they heard the certain songs that are used to teach a poem to them. A study explored the value of content-based music in the classroom as it is difficult to find in a normal classroom. The researchers used songs as a teaching strategy in kindergarten, second, and fifth grade classrooms across multiple content areas. The findings indicate that there are gains in subject matter knowledge and student participation in class activities increased when content-based music is implemented as a teaching strategy (Campbello et al., 2002).

Furthermore, according to Jensen (2015), songs, specific melodies, rhythms, and tones all have the potential to engage content learning in this way. It has been viewed that if songs are integrated in delivering lessons in class, may it be math art, history, or literature, there is a bigger chance that learning will not only take place but engaging participation will also be evident as active responses can be provided by students throughout the class discussion and a higher progress on performance among students can be a success indicator when songs are used.

\subsection{Emerging Theme 2: Use of Songs and Calligrams as a Technique}

There are emerging and up-to-date techniques, methods, and strategies to be used in dealing with literature, specifically poetry. There are also strategies where teachers can integrate both traditional and modern method of teaching and learning literature through various activities to be provided for students. Teachers can no longer deprive themselves of learning and exploring the $21^{\text {st }}$ century strategies that are helpful for the success of the transfer of learning between teachers and students. According to Hennessy, Hinchion, and McNamara (as cited in Sugandi \& Husnaini, 2015), to gain pupils' understanding in poetry, the use of illustration of poetry, drama-in-education techniques, and poetic composition are very helpful in the classroom. In addition, Tweddle, et al. (as cited in Xerri, 2012) emphasised the fact that "the changes enabled and driven by technology have become so far-reaching that for English teachers to ignore them would prove ultimately irresponsible." With the fast-paced growth in technology and modernization of the world, it is not only business that should cope with these changes; education should as well cope and be at the beat of the outgrowing technology-based software that can be helpful in their daily class encounter with students. Students are inclined to technology such as cellphones and iPads that most of their time are spent on gadgets and with this, teachers must maximize the use of these gadgets in learning poetry as it will not only be beneficial for students but also for teachers.

\subsection{Emerging Theme 3: Challenges in Using the Two Methods}

Collie and Slater (as cited in Sugandi \& Husnaini, 2015) gave some important reasons why teachers use literature in the classroom. According to them, teachers can get authentic materials from literature, they can share cultural knowledge to their students, they can help students to improve their skills in language, and students can develop their personalities through literature. Literature has been part of the education curriculum ever since as it embodies the rich culture, values, and tradition of a certain ethnicity or person. It shows the historical background of a country or race. As years go by, teaching literature has become less and less interactive as it became passive. No more concrete responses can be drawn out among students as they no longer engaged themselves in the learning process. One of the most important problems Parkinson and Thomas observed was "the likely imbalance of knowledge and likely imbalance of power between teacher and learner" (Parkinson and Thomas as cited in Al-Mahrooqi, 2012). Teachers are more knowledgeable when it comes to literature than students. They know more about it and they can easily interpret it but the question is if the students can do the same. The interactive learning will take place if the teachers allow the students speak their thoughts regarding the poem taught because it will be one proof that students learn something.

Furthermore, Collie and Slater (as cited in Sugandi \& Husnaini, 2015) suggested that teachers should "add fresh momentum into the teaching of literature by stimulating students' desire to read and encouraging their responses". Using songs and calligrams in teaching poetry will make a great difference when it comes to the 
performance and participation of the students. These will allow concrete and unique responses among students where teachers can stimulate responses from them despite the difficulty to understand the words. The purpose of using songs and calligrams is to help students understand easily what the poem is all about - not only the content but its context as a whole. They can also relate their experiences and share it to class or even make them create their own poem through calligrams. In addition, there is a reason as to why there is less interaction of learning before songs and calligrams were used inside the classroom. According to Sidhu (as cited in Norliana, 2008) students were dissatisfied with the texts due to the mismatch in language levels and interests, and feel that they could not understand the texts due to their lack of proficiency in English. It is a hindrance for students to speak or participate during class discussion for aside from the fact that they cannot understand the pome, they were not confident enough to speak the language.

Lastly, Aguilar (2013) stated that there is a reason why schools need to teach poetry in schools. It is when read aloud, poetry is rhythm, music, sounds, and beats. Young learners may not understand all the words or meaning, but they will feel the rhythms, get curious about what the sounds mean, and may want to create their own. Contrary to popular belief amongst students, boys get really into poetry when brought in through rhythm and rhyme. It is the most kinesthetic of all literature, it is physical and full-bodied which activates one's heart and soul and sometimes bypasses the traps of the mind and the outcome is that poetry moves all readers.

\subsection{Emerging Theme 4: Improvement of Macro Skills and Competencies}

Literature does not only enhance the macro skills of the students; it also developes the creativity of the students as teachers allow them to produce or at least write their own poem interpretation depending on how they want to express their artistry. Creativity is not all about the artistry of a person that is being developed in studying literature. As explained by Sharminnie, Vasuthavan, and Kunaratnam (as cited in Sugandi \& Husnaini, 2015), in helping students develop an appreciation and understanding of poetry, there are two fundamental principles to keep in mind. First, poetry must be read aloud. Second, poetry should be enjoyed. In teaching poetry, teachers must have great effort to make students enjoy with this activity in order to achieve effective teaching and learning.

Similarly, poetry encourages children to think outside the box. The imaginative nature of poetry shows students that there can be different interpretations of a single work, adds education consultant (Planbook.com, 2020) "There are often no 'right answers' when discussing poetry. Poetry is therefore supportive of encouraging children to think beyond the literal and into the abstract," she explained. Creativity has been developed in studying literature since teachers give task to their students such as drawing an image or poem interpretation, through role playing, or sketching in which students can show the ideas or the interpretation they made for the poem they have read. Additionally, Hennessy, Hinchion, and McNamara (as cited in Sugandi \& Husnaini, 2015) stated that to gain pupils' understanding in poetry, the use of illustration of poetry, drama-in-education techniques, and poetic composition are very helpful in the classroom. Literature supports students to develop four language skills. Reading and writing skills can be enhanced through literature by transferring both skills from the first language to the foreign language. Literature helps students gain their knowledge of language and improve their reading and writing abilities (Hedge as cited in Sugandi \& Husnainbi, 2016).

Furthermore, Parkinson and Thomas (as cited in Sugandi \& Husnaini, 2015) listed the importance of literature as follow: students can understand about cultural awareness through reading literature; they can learn a good composition in writing through literature; they can exercise their mind and sensitivity; they can learn more about linguistic competence; they can learn directly because literature is an authentic material; they can learn how to memorize poetry and songs well and it can be applied in learning English when they want to memorize the new words; they can motivate themselves through literature because it is generated by some authentic impulse on the part of the writer and deals with subjects and themes that are interesting to the students; they can interact with each other because literature gives open interpretation in terms of meaning; and they can write directly because it is a handy resource.

106 Consortia Academia Publishing (A partner of Network of Professional Researchers and Educators) 
Obediat (as cited in Sugandi \& Husnaini, 2015) asserted that literature helps students acquire a native-like competence in English; it helps them express their ideas in good English. They also learn the features of modern English; and learn how the linguistic system of English language functions when it is used for communication. The students see how certain idiomatic expressions are used; they learn how to speak clearly, fluently, and accurately. According to Abraham (as cited in Habeeb \& Firwana, 2015), "Learning Literature not only improves the basic skills like reading, writing, listening and speaking but also other language areas such as vocabulary, grammar and pronunciation. One of the prerequisites for language learning is that students should have a feeling for the language, which can be achieved through creative and critical use of literary texts where they can experience language in use." Therefore, the study of literary texts will enhance the learners' language competence in general and the performative skills (speaking and writing) in particular.

In addition, Britsch (as cited in Alfauzan \& Hussain, 2016) highlighted these benefits by stating that using stories in teaching enhance students' common sense, improve their reading and writing, help students make sense of the world around them, strengthen literary and reflective skills, suit a whole language curriculum, and enrich students' creative and imaginative skills. Moreover, Aguilar (2013) stated that there are reasons why schools need to teach poetry in schools. These reasons are: poetry opens venues for speaking and listening which have been much neglected domains of a robust English Language Arts curriculum. Through spoken word and poetry slams - shared in this way, poetry brings authentic audience which motivates writers. Also, poetry has space for English Language Learners. Because poems defy rules, poetry can be made accessible for them -- poems can be easily scaffolded and students can find ways of expressing their voices while being limited in their vocabulary. Furthermore, poetry is universal. Learners can learn about or read poetry in their primary language, helping them bridge their worlds.

\subsection{Emerging Theme 5: Observed Changes in the Students during Transition Period}

In the use of songs and calligrams, teachers and students both made a big transition in the normal way of teaching and learning poetry. From the paper and pen, and passive delivery of poetry in class, it has become engaging and fun since the teacher focuses on the students' understanding of learning the message and context of a whole poem. According to the article by The Editorial Team (2020), Teaching poetry through song lyrics was a great way to get a class to pay attention to a sometimes-tedious lesson. By breaking down and closely examining lyrics to contemporary songs, teachers can introduce students to the basic mechanics of writing poetry using sentences they already know. First, it calms students and gets them quiet for class time. Second, they will likely catch on to the rhythm and some lyrics, but it will not ruin the rest of the lesson plan. The lesson might include several poetic devices, such as metaphors, similes, personification, assonance, hyperboles, rhetorical devices/questions, rhyming, onomatopoeia, epistrophe, and alliterations. It became more engaging and exciting when teachers started to try incorporating new techniques such as the sue of songs and calligrams in their teaching of poetry as it is dimmed to be boring by all students. With the use of this new technique, there is a big difference when it comes to the participation or engagement of the students during the teaching and learning of poetry inside their classroom.

\subsection{Emerging Theme 6: Suggestions in Using Songs and Calligrams}

Collaborative learning (CL) can be defined as a set of teaching and learning strategies promoting student collaboration in small groups (two to five students) in order to optimize their own and each other's learning (Johnson and Johnson, 1999). In addition, Cooperative learning is known as a most important active learning technique by grouping students together to accomplish both individual and group learning goals (Prince, 2004). It has many variants, such as the general cooperative learning model, jigsaw model, and graffiti model (Kilbane \& Milman, 2014). Students best learn when they work in a group as there is a higher stake of learning while sharing ideas with others. The mind that works with others can come up with better ideas because they tend to brainstorm and put each idea in one output. Collaborative activities in literature will boost engagement and interest among learners as teachers can provide activities for students and they can work on with their classmates. 
Furthermore, Slavin (2002) and Johnson and Johnson (2009) confirmed its benefits which are manifested in academic growth such as improved academic achievement and critical thinking; in psychological health (Slavin, 2002; Nolinske \& Millis, 1999), such as enhanced self-esteem and lower level of stress and anxiety; and in social skills (Nagel, 2008; Lemming, 1992), such as more supportive relationship with classmates and the acquisition and enhancement of communicative skills.

\subsection{Emerging Theme 7: Students' Performance in Both Techniques}

Literature for over the years has been part of English curriculum in which teachers struggle to teach and deliver in class where they supposed to provide good insight and understanding among students. Over the years, teachers have been stuck with one way of teaching literature, especially poetry, that end up for students finding it difficult to understand and boring to learn. Students struggle a lot because they think learning poetry is like a math problem wherein you look for a solution to the problem that doesn't exist. Killander (2011 as cited in Haniya, 2019) described four challenges in teaching and learning poetry in language classrooms: Teachers and students should have extra thinking to get the meaning of poems that they read, teachers and students get difficult because of linguistic aspects, some students feel bored in reading poetry because they cannot get the benefits from that activity, and teachers do not have the confidence to struggle, bare all or take such chances in teaching. Nowadays, some teachers are not fond of teaching literature inside their English class. They prefer to focus on the linguistic sides of the class since they think that it is a lot more important in the classroom discussion. Little do they know that Literature is one of the biggest parts of the development of the behavior of the students if the teachers have the guts to teach well the literary piece inside the classroom. The struggle of the teachers in teaching poetry is their engagement to the poem within themselves. There are instances that during literature class, students' behavior and attitude in learning can be affected by the teacher's way of presenting himself in the class discussion. If the teacher, himself, is not well-versed, prepared, and eager, he can make his students understand and joy the literature throughout the discussion. Students, with the use of new techniques and strategies, can help them build the love and appreciation for poetry since they can understand the message or the whole context of the poem the author wants to deliver to the readers that have relatable meaning and message which can be related to the present time.

\subsection{Emerging Theme 8: Challenges in Oral and Written Discourse}

Oral and written discourse are very important to be developed in terms of learning literature as it helps develop the way the students communicate and express their thoughts through oral and written forms. Students nowadays find it hard to establish communication, may it be written or oral, as they struggle to use words that are appropriate in the oral and written communication. Khansir (as cited in Sugandi \& Husnaini, 2015) stated that "poetry is example of a more intense use of language". Through learning poetry, students can use the language more and express what they want to write. In literature, students are taught how they could express their own thoughts and ideas through different forms of discourse. In writing, it will help the student to develop the importance of pre-writing, writing, and post-writing. It will allow students to check and look on what they had written.

Students of the $21^{\text {st }}$ century struggle to communicate what they know because they find it hard to understand even a single word. Vocabulary words are very important, especially if students are writers or speakers, as they cannot use the same words every time. The redundant use of words may lead to incoherence of what they are trying to say or write. Parkinson and Thomas (as cited in Al-Mahrooqi, 2012) addressed these problems faced by language learners. They mentioned that the remoteness of a particular text and the use of odd language can be challenging. Students sometimes cannot relate to the text and this may affect their interpretation of some of the embedded ideas in it. In addition, Abraham (as cited in Habeeb \& Firwana, 2015), cited that "Learning Literature not only improves the basic skills like reading, writing, listening and speaking but also other language areas such as vocabulary, grammar and pronunciation." 
There is a big concern when students have no clear understanding of the meaning of the words that they encounter in a poem. The students struggle a lot in writing or speaking their thoughts on what they have understand during the discussion. Furthermore, Britsch (as cited in Alfauzan \& Hussain, 2016) highlighted these benefits by stating that using stories in teaching enhance students' common sense, improve their reading and writing, help them make sense of the world around them, strengthen literary and reflective skills, suit a whole language curriculum, and enrich students' creative and imaginative skills.

\subsection{Emerging Theme 9: Addressing the Challenges in Both Methods}

In a literature class, words are given for students to look for their meanings so that they can easily understand what the words mean and help them understand the poem as a whole. It has been a struggle for students to understand a poem because of the unfamiliar words present in it. It sometimes led to confusion and delay of understanding among students. That is why teachers allow their students to use different materials which can help them know the meaning of the words and one of these is a dictionary. Dictionaries have been very helpful to students even before they became accessible in the internet. Sometimes, if a dictionary is not available, teachers tell their students to use context clues to help them know the meaning of the words they are unfamilar with based on how they are used in the sentence.

Additionally, as stated in Cubuku (as cited in Sugandi \& Husnaini, 2015), "poems pose a challenging cognitive task. Readers must first have a basic understanding of a concept or emotion and then transform that understanding into meaningful creative expression by exploring and distilling complex ideas." Poetry is full of complex ideas that cannot be easily understood if there is no clear understanding of the whole content. Words are challenges for students as some poetry use deep words or sometimes old English words that students cannot decipher the meaning. That is why they tend to seek help or search the meaning of the words through a dictionary or the internet, whichever may be accessible to them.

\subsection{Emerging Theme 10: Comparison of Using the Two Techniques}

Teachers, during their literature class, find it difficult to discuss a piece, particularly poery, among students as they only have limited resources for their instructional materials which may result to passive interaction and learning among teachers and students. According to Killander (2011 as cited in Sugandi \& Husnaini, 2015), there have been four challenges in teaching and learning poetry in language classrooms: teachers and students should have extra thinking to get the meaning of poems that they read, teachers and students have difficulty with linguistic aspects, some students feel bored in reading poetry because they cannot get the benefits from that activity, and teachers do not have the confidence to struggle, bare all, or take such chances in teaching.

The success in learning poetry is not only dependent on the teacher but on the students as well as the transfer of learning is a two-way process where both students and teachers need to reciprocate with each other. If a teacher is the only one willing to learn and understand a literary topic, it will be hard for the students to at least establish within themselves the understanding of the whole context of the piece. Another challenge that the teachers can encounter in using the traditional and new technique in teaching poetry is that they attend class without learning and understanding the poem that may result to confusion among students and for them not to fully understand it since it has an in-depth meaning that cannot be easily understood by them without their teacher's help.

\section{Conclusions}

Literature teachers had provided the responses and definite experiences on the teaching of literature using the traditional method first, and recently, songs and calligrams. The shift made on teaching literature from what has been known to the integration of modern ways to teach literature is at its advantage as the teachers will find it easy and convenient for them to deliver the literary texts inside the classroom. The teachers, together with the students, have shown that the traditional way of dealing with literature has been difficult for both participants as 
they were having a hard time in transcending the learning across learners because the teachers in a traditional classroom did more talking and explaining, while students listened and answered only when asked which resulted to passive interaction among teachers and learners. Additionally, with the wide range and boost of technology such as cellphones, iPads, and other technological-based tool or application, different fields started adapting to these changes and educational institution is one of them. Teachers agreed that teaching literature using technology has been helpful and beneficial for the students because they engage themselves during the class discussion. Integration of modern methods in teaching literature, such as the use of songs and calligrams, has been a game-changer in the teaching and learning of literature because it has been convenient and interactive and the success rate and progress on the students' performance have been evident.

There is a big difference when it comes to the teaching and learning of poetry when dealing with it the traditional way compared to doing it through the use of songs and calligrams. Furthermore, teachers and students believed that when they tried to engage themselves in the use of songs and calligrams, they were able to change the way they viewed poetry. They developed interest, love, and appreciation for literature while being knowledgeable on its whole context. Also, they agreed that the continuous use of songs and calligrams in teaching and learning poetry enhanced the competencies and skills of the students such as listening, writing, speaking, and reading which are essential for the development of the language skills of the students. Moreover, the end goal of teaching literature is to transfer learning and understanding without developing fear and hesitation in students for speaking out their ideas and thoughts.

Despite the struggles they encountered in dealing with poetry through different methods, the participants were able to cope with the adjustments they experienced when they started using songs and calligrams and there was a great impact on the performance and success of the teaching-learning process inside the classroom. Throughout this study, the researcher had verified that teachers and students were encountering problems in using the traditional method inside the classroom; but with the shift they made in dealing with poetry through songs and calligrams, they were able to manage and address the problems they encountered to be able to succeed in developing the enthusiasm, love, and appreciation for literature.

During the interviews, the researcher realized how these teachers handled literature and looked for different ways that would help them deliver literature among students who were having difficulty understanding the texts being discussed. They became open to changes and new strategies which they could use in teaching poetry to their students, especially that teachers are engaging 21 st-century learners who have a short attention span and have shown a lack of interest every time they encounter literature, specifically poetry. There were instances that at the end of every class discussion, the teachers could see that students did not gain anything or if they did, it was limited to the best of what they could understand that made it hard for them to express their thoughts and ideas. In the traditional method, usually, there was less interaction between teachers and students and there was less rapport in class because the teachers were the ones who were responsible for explaining and analyzing the poem so that the students could understand it and be able to draw out responses for questions being asked.

Students, on the other hand, experienced the same things and the researcher realized that with students nowadays becoming more engaged in technology, they cannot focus and build interest in learning poetry as they find it boring and uninteresting. This is because they see literature, specifically poetry, as a math problem that is hard to understand and decipher without them knowing what the real context of learning it is since they have been taught only the content of the whole poem.

With songs and calligrams, the researcher realized that both teachers and students proved that learning took place when they used songs and calligrams in dealing with poetry. This shows that the active participation of the students has been one result caused by the use of songs and calligrams in teaching and learning poetry. As the educational system changes, strategies and techniques are being modified to cater to the needs of the learners especially that they are taught to become globally competitive individuals in the future. Also, appreciation and love for reading will start from appreciating literature being taught inside the classroom. Small progress will still 
Making lit a hit: Teaching and learning poetry in grade 9 through songs and calligrams

be progress. Teachers and students should work together to be able to develop not only the language but also the appreciation among students. Also, literature will bridge the gaps between the cultural and historical boundaries that will allow students and teachers to be well equipped when it comes to content-based learning of literature.

As a literature teacher, the researcher believes that to leverage the reading skills of her students, the use of technology-based tools or activities will be of great help in handling her class since she aims for a higher rate of reading skills among her students. Also, she believes that songs and calligrams will be one of the techniques she can use to convey conveniently the poems the students need to know. However, despite the advantages the songs and calligrams offer, there are still instances where teachers prefer the traditional way of teaching literature as they do not need to think of the appropriate songs to use that will be applicable for the texts they will discuss in the next meeting. Therefore, teachers need to exert an amount of effort to leverage their strategies and update the teaching method they use to be at peace with the changes in teaching literature.

During the transcriptions, the researcher understood that the teachers and students were open to the adjustments they made when they started using songs and calligrams in their classes. The songs and calligrams elicited a higher stake of interaction and active participation among students that allowed them to speak out their ideas and thoughts regarding certain texts. They all agreed that the traditional method may still be utilized by integrating songs and calligrams into it. The combination of both techniques can somehow promote success and can greatly affect not only teachers' perspectives about literature but also students' attitudes towards it. They believed that if songs and calligrams were implemented and used inside the class, it would promote an attitude of appreciation and genuine love for literature.

To conclude, the experiences of students and teachers when it comes to dealing with poetry through songs and calligrams have an impact on their attitudes and perspective in literature. One of the main reasons for the success of the teaching and learning of poetry is how the teachers view and manage to come up with various activities that can be easily utilized and used inside the classroom in terms of songs and calligrams. Also, despite the struggles both teachers and students encountered in dealing with poetry, they still managed to foster and develop with each other the love and appreciation for literature. Therefore, with the use of songs and calligrams, the teachers can solicit concrete responses from students that can open the world of rich culture and history.

\section{References}

Abuzahra, N. A. A., \& Farrah, M. A. A. (2016). Using short stories in the EFL classroom. Department of English, Faculty of Arts, Hebron University, Hebron, Palestine.

Aguilar, E. (2013). Five reasons why we need poetry in schools. Edutopia. https://www.edutopia.org/blog/five-reasons-poetry-needed-schools-elena-aguilar

Alase, A. (2017). The Interpretative Phenomenological Analysis (IPA): A guide to a good qualitative research approach. International Journal of Education \& Literacy Studies, 5(2).

Alexander, K., \& Colderley, C. (2015). Making words dance. https://www.languagemagazine.com/2015/08/13/making-words-dance/

Alfauzan A. H., \& Hussain, A. G. (2016). Attitude towards and perception of literature in EFL setting: A case study on QU male undergraduate students. College of Arabic \& Social Studies, Qassim University, Buraydah, Saudi Arabia. https://files.eric.ed.gov/fulltext/EJ1123152.pdf

Al-Mahrooqi, R. I. (2012). EFL student attitudes towards studying literature at a higher education institution in Oman. European Journal of Social Sciences, 32(1), 1450-2267.

Alshammari, H. A., Ahmed, E. A., \& Shouk, M. A. A (2020). Challenges to studying the English literature by the Saudi undergraduate EFL students as perceived by instructors. Department of English, College of Arts, Jouf University, Sakaka, Saudi Arabia.

Antika, R. (2017). Poetry in EFL classroom. STKIP PGRI Sumatera Barat.

Arafah, B. (2018). Incorporating the use of literature as an innovative technique for teaching English. English Department, Faculty of Cultural Sciences, Hasanuddin University, Indonesia. 
Nieves, T. P. F., \& Recillo, M. L. B.

Art Sprouts. (2019). How to create Calligram poetry: Surrealism art interdisciplinary lesson plan. https://www.artsproutsart.com/how-to-create-calligram-poetry-surrealism-art-interdisciplinary-lesson-pl an/

Batou, G. (2011). Project educate: Visual and concrete poetry. https://www.deviantart.com/gaioumonbatou/journal/Project-Educate-Visual-and-Concrete-Poetry214242913

Benzoukh, H. (2017). The relevance of teaching different literary genres in the EFL classroom. Kasdi Merbah University, Ourgla, Algeria.

Choudhary, S. (2016). A literary approach to teaching English language in a multicultural classroom. Department of English, University of Rajasthan, Jaipur, India.

Department of Persian literature. (2020). Khodabandeh Branch, Islamic Azad University, Khodabandeh, Iran. https://popups.uliege.be/0037-9565/index.php?id=6292\&file=1

Editorial Team. (2020). Advice for teaching poetry through song lyrics. Resilient Educator. https://resilienteducator.com/classroom-resources/advice-for-teaching-poetry-through-song-lyrics/

Ellestrom, L. (2016). Visual iconicity in poetry: Replacing the notion of "visual poetry”. Linnæus University.

Fetalver, E. M., \& Legaspi, M. L. (2019). Improving comprehension and retention through last story syndrome approach. The College of Graduate Studies and Teacher Education Research, Philippine Normal University, Manila.

Ghazali, S. N. (2008). Learner background and their attitudes towards studying. Malaysian Journal ELT Research, 4.

Gourvennec, A. F., Höglund, H., Johansson, M., Kabel, K., \& Sønneland, M. (2020). Literature education in Nordic L1s: Cultural models of national lower-secondary curricula in Denmark, Finland, Norway and Sweden.

Governor, D. (2011). Teaching and learning science through song: Exploring the experiences of students and teachers. Department of Science Education, University of Georgia, Athens, GA, USA.

Habeeb, A. S., \& FirwanaI, S. S. (2015). IUG English major education- Track students' attitudes towards literature courses. Department of English, Islamic University of Gaza.

Haniya, A. (2019). Literary materials selection for teaching English language and literature subject at senior high schools in Sidoarjo. English Teacher Education Department, Faculty of Tarbiyah and Teachers Training, Universitas Islam Negeri SunamAmpel Surabaya.

Heinemann Authors. (2020). Teaching and learning through poetry. https://blog.heinemann.com/teaching-and-learning-through-poetry

Holden, L. (2016). Studies in visual poetry: Poetry, research, motion design, book design, interactive design. http://laurenholden.ca/studies/poetry.html

Karasfi., N. D. M. (2016). Half an analytical look at the history of the emergence of Concrete poetry. Bulletin de la Société Royale des Sciences de Belgique, 85, 1588-1600.

Karuna, B (2016). Literature as an effective tool for teaching ESL. Department of English, Acharya Nagarjuna University.

Kaşlığlu, Ö., \& Ersin, P. (2018). Pre-service teachers' beliefs about literature integration in English language teaching classrooms. Journal of Language and Linguistic Studies, 14(3), 213-232.

Kataja, R. (2018). The use of literature in the EFL classroom: Students' perception. Department of Language and Communication Studies, University of Jyvaskyla.

Kempton, K. (2005). Visual poetry: A brief history of ancestral roots and modern traditions. http://glia.ca/conu/digitalPoetics/prehistoric-blog/wp-content/uploads/karl-kempton-visual-poetry-a-brie f-introduction.pdf

Keshavarzi, A. (2015). The effect of cooperative learning on reading comprehension and reading anxiety of pre-university students. Journal of Applied Linguistics and Language Research, 2, 169-180.

Khan, S. (2020). Why and how to use a poem in ELT classroom. International Online Journal of Education and Teaching, 7(3), 803-809.

Liikkanen, L. A., \& Jakubowski, K. (2020). Involuntary musical imagery as a component of ordinary music 
Making lit a hit: Teaching and learning poetry in grade 9 through songs and calligrams

cognition: A review of empirical evidence. Psychon Bull Review, 27, 1195-1217. https://doi.org/10.3758/s13423-020-01750-7

Maples, J., Cianca, M., \& Maloy, M. (2016). Using graphic novels to engage English language learners. Vanguard, 45(1), 37-39.

Marsh, J. (2020). The real work. Inside Higher ED. https://www.insidehighered.com/views/2020/05/01ortance-poetry-challenging-times-and-how-teach-stu dents-about-it-opinion

Mittal, R. (2016). Poetry is language at its most distilled and powerful: Bringing poetry in language classes can make language understanding and communication skills better. Linguistics and Literature Studies, 4 , $52-56$.

Mohammed, K. (2013). Investigating EFL learners'attitudes towards literature teaching methods: Case of $2 n d$ year LMD Students at the University of Tlemcen. http://dspace.univ-tlemcen.dz/bitstream/112/3321/1/kheladi-\%20mohamed\%20Ghouti\%20MAG\%20A NG.pdf

Msibi, T. N. (2016). Teaching Siswati poetry and pre-/in-service training experiences of teachers in selected high schools of the Hhohho Region in Swaziland. School of Education Edgewood, University of Kwazulu-Natal

Nordquist, R. (2019). Stylistics and elements of style in literature. https://www.thoughtco.com/richard-nordquist-1688331

Planbook.com. (2020). Why are we learning this? Teaching poetry supports cognitive thinking and empathy. https://blog.planbook.com/teaching-poetry

Poets.org. (2004). A brief guide to concrete poetry. https://poets.org/text/brief-guide-concrete-poetry

Rahimpour, S. (2020). The impact of literature teaching techniques on the learners' performance on academic reading course tests. Applied Linguistics Research Journal, 4(1), 53-62.

Ringe, L. A. (2020). Performing poetry: Acquiring robust words. Michigan Reading Journal, 51(2), 4. https://scholarworks.gvsu.edu/mrj/vol51/iss2/4

Saadatnoori, H., Moshayedi, J., \& Haidary, H., (2020). Understanding the language of political. Persian Language and Literature Department, Arak University, Arak, Iran.

Secondary English - Using Song Lyrics to Teach Poetry. (2012). https://freedomtoteach.collins.co.uk/secondary-english-using-song-lyrics-to-teach-poetry/

Siaj, R., \& Farrah, M. (2018). Using novels in the language classroom at Hebron University.

Simmons, A. (2014). Why teaching poetry is so? https://www.theatlantic.com/education/archive/2014/04/why-teaching-poetry-is-so-important/360346/

Singh, S. (2016). Game based language learning in ESL classroom: A theoretical perspective. International E-Journal for Research in ELT.

Snyder, S. (2016). Teachers' perceptions of digital citizenship development in middle school students using social media and global collaborative projects. Walden University, Minnesota, USA.

Stan, R. V. (2016). The importance of literature in primary school pupils' development and personal growth. University of Pitesti, Romania. https://pdf.sciencedirectassets.com/

Sugandi, B., \& Husnaini. (2015). Teaching poetry for creative and higher order thinking skills. The 3rd International Multidisciplinary Conference on Social Sciences. Bandar Lampung University. http://www2.vobs.at/ludescher/Grammar/teaching_grammar_through_songs_a.htm

Syed, A. J., \& Wahas, Y.M.A. (2020). Challenges and solutions in teaching English through poetry to EFL Students at Hajjah University: A case study of William Wordsworth's Lucy and John Donne's Death Poems.

Tevdovska, E. (2016). Literature in ELT setting: Students attitudes and preferences towards literary texts. Procedia - Social and Behavioral Sciences, 232, 161-169. https://doi.org/10.1016/j.sbspro.2016.10.041

Violetta-Irene, K. (2015). The use of literature in the language classroom: Methods and aims. International Journal of Information and Education Technology, 5(1), 74-79.

Wijayanti, D. N. (2013). Constructivism theory of language teaching and learning. 
Nieves, T. P. F., \& Recillo, M. L. B.

https://mydreamarea.wordpress.com/2013/01/05

Xerri, D. (2012). Poetry teaching and multimodality: Theory into practice. Department of English, Junior College, University of Malta, Malta. 